Limnol. Rev. (2015) 15, 1: 39-50

\title{
Analysis of the exposure of Polish lakes to flood risk
}

\author{
Anna Pasiecznik-Dominiak, Andrzej Tiukało, Grzegorz Dumieński
}

Institute of Meteorology and Water Management, Branch in Wrocław, Parkowa 30, 51-616 Wrocław, Poland, e-mail: Anna.Pasiecznik@imgw.pl (corresponding author); Andrzej.Tiukalo@imgw.pl; Grzegorz.Dumienski@imgw.pl

\begin{abstract}
Flooding constitutes one of the main natural hazards in Poland, which causes enormous social, economic and environmental losses. The main causes of the occurrence of floods include intensive rainfall, rapid melting of snow and ice cover, as well as strong gusts of wind from the sea. Based on the resilience theory (resistance, elasticity), which constitutes an efficient tool for the description of the social-ecological system capability or components thereof to mitigate the effects of dangerous events, as well as the capability of reconstructing and adapting the system to new conditions, the authors have analysed the exposure of Polish lakes to flood risks with a probability of occurrence Q $0.2 \%$, Q1\% and Q10\%. In order to determine the level of exposure of lakes to the risk of flooding by flood waters, studies were conducted using the flood hazard and flood risk maps which were developed under the Project entitled "IT System of the Country's Protection against Extreme Hazards". The result of the efforts of the group of authors is the determination of the number of lakes, which are located in the flood risk area Q0.2\%, Q1\% and Q10\%, including division into risk level groups (low, moderate and high). The results presented in the paper may constitute a contribution to further, more detailed studies concerning assessment of the vulnerability of Polish lakes located in the flood prone area.
\end{abstract}

Key words: social-ecological system, flood risk, flood hazard, exposure, sensitivity, vulnerability

\section{Introduction}

Flooding is one of the most frequent natural disasters in Poland (RCB 2010). It may be caused by intensive rainfall, rapid melting of snow and ice cover on rivers, strong gusts of wind from the sea or the failure of pooling water structures, as well as of flood preventive structures. Along with the development of urbanisation and the increasing violence of extreme weather events, floods in recent years have had an increasingly adverse impact on the sense of safety amongst the society, and generate increasingly severe losses in the economy and the natural environment (Strzelecka 2014; Zwoździak 2015).

In spite of many activities, it is not possible to completely eliminate the risk of floods (so-called residual risk). Implementation of a combination of measures, both technical and non-technical, may only reduce the risk of the occurrence of adverse effects of flooding. To ensure efficiency of these actions it is necessary to inform and raise public awareness of the flood threat and risk (Gromek 2014; Strzelecka 2014).
One of the methods to prevent floods and reduce their adverse effects is rational spatial policy and avoidance of development of areas in which floods may cause great losses (both social as well as economic and environmental). Therefore it is so important to identify all areas at risk of flood waters in Poland, and to evaluate the elements of social-ecological systems of great importance which are potentially located within the boundaries of a probable occurrence of this phenomenon.

According to the definition (UNISDR 2007) exposure defines those elements of the system (people, buildings etc.) which are located in the flood risk area and may cause or be a source of potential losses. The social-ecological system (SES) (Holling 1973) is considered as a system of closely related and interplaying components of geographic space, its natural resources, on one side, and human capital on the other side (Holling 1973). Both components are conditioned by cultural and historic factors, as well as political and economic ones (Tiukało and Dumieński 2013). 
In consequence, lakes presented in the further part of the article constitute components of social-ecological systems. SES may be considered as an administrative district (Tiukało and Dumieński 2013) or commune (Dumieński, Michalik et al. 2015; Dumieński, Pasiecznik-Dominiak et al. 2015). The authors have thus identified the elements (of exposure) - Polish lakes - for all three scenarios of flood occurrence. This is the continuation of research works conducted by the Institute of Meteorology and Water Management - PIB Branch in Wrocław, which concern an assessment of Polish social-ecological systems exposed to adverse effects of flood waters (Dumieński, Pasiecznik-Dominiak et. al. 2015).

In order to improve the safety of the citizens, a Project entitled "IT System of the Country's Protection against Extreme Hazards" (Polish: "Informatyczny System Osłony Kraju przed Nadzwyczajnymi Zagrożeniami" - abbr. ISOK) was set up, which supports Poland's obligations associated with the implementation of the so-called Flood Directive (Directive $2007 / 60 / W E$ ), which constitutes an efficient tool for identification and management of flood risk.

An initial flood risk assessment (Polish: wstępna ocena ryzyka powodziowego - abbr. WORP) was conducted under the ISOK Project, which defines the most important areas at risk of flooding in Poland, characterised by the greatest probability of the occurrence of flooding, causing a threat to people's life and health, as well as considerable economic and environmental losses. The aim of WORP was to identify rivers or river sections and embankments for which precise spatial data had been prepared, i.e. digital models of terrain and cross-sections of river beds, as well as hydrological data necessary to conduct hydraulic modelling, which lays the basis for the preparation of flood hazard maps (Polish: mapy zagrożenia powodziowego - abbr. MZP). For the areas identified by WORP - also under the ISOK Project - flood hazard maps and flood risk maps (Polish: mapy ryzyka powodziowego - abbr. MRP) were developed. Documents supplementing the above works will be Flood Risk Management Plans (Polish: Plany Zarzadzania Ryzykiem Powodziowym $a b b r$. PZRP) for river basin areas and water regions, considering PZRP on the side of the sea, including internal marine waters (Tiukało and Sadowska 2015).

The flooding range areas presented in MZP are a basis for spatial planning at various levels. Borderlines of areas under threat of flooding are considered, amongst others, in the country's spatial development conceptions, provincial spatial development plans, local spatial development plans, and in decisions concerning the determination of the location of public purpose investments or in planning permission decisions. An example of a flood hazard map, developed within the framework of the ISOK Project, is presented in Figure 1. Flood hazard maps are available to the public at the ISOK Project website (http://mapy.isok. gov.pl/imap/).

\section{Methods}

The source of information on the exposure of Polish lakes to the threat of flooding occurrences is flood hazard maps. Flood hazard maps present areas at risk of flooding with a particular probability of occurrence (Directive 2007/60/WE): (i) areas in which the probability of flooding occurrence is low and equals $0.2 \%$ (i.e. once per 500 years; a so-called 500 -year flood); (ii) areas in which the probability of flooding occurrence is moderate and equals $1 \%$ (i.e. once per 100 years; a so-called 100 -year flood); (iii) areas in which the probability of flooding occurrence is low and equals $10 \%$ (i.e. once per 10 years; a so-called 10-year flood).

Lakes, due to their great importance for local communities, have become an object of many studies conducted by limnologists (Bogdanowicz et al. 2012). This enables assessment of the impact of climate changes on lake ecosystems and determination of threats, which may become obstacles for the use of lakes in the future.

Studies have contributed to the assessment of the status of lakes, which allows us to expand our knowledge on the weaknesses of the environment and the future threats associated with this. Based on the studies and analyses conducted on the impact of climate changes on lakes, common risk assessment and lake vulnerability methods have been developed. The main criteria used by limnologists while assessing vulnerability of lakes include the following: changes in water resources, water temperature, water quality, damage to the shoreline, damage to reed rushes, presence of invasive species, impact on agriculture, fishery, human health and tourism. All problems are interrelated and totally inter-dependent; maintenance of a constant water balance has a positive influence on the development of tourism, which in turn results in urbanisation of the lakes' shoreline and destruction of natural reed rushes, which act as a natural filter for 


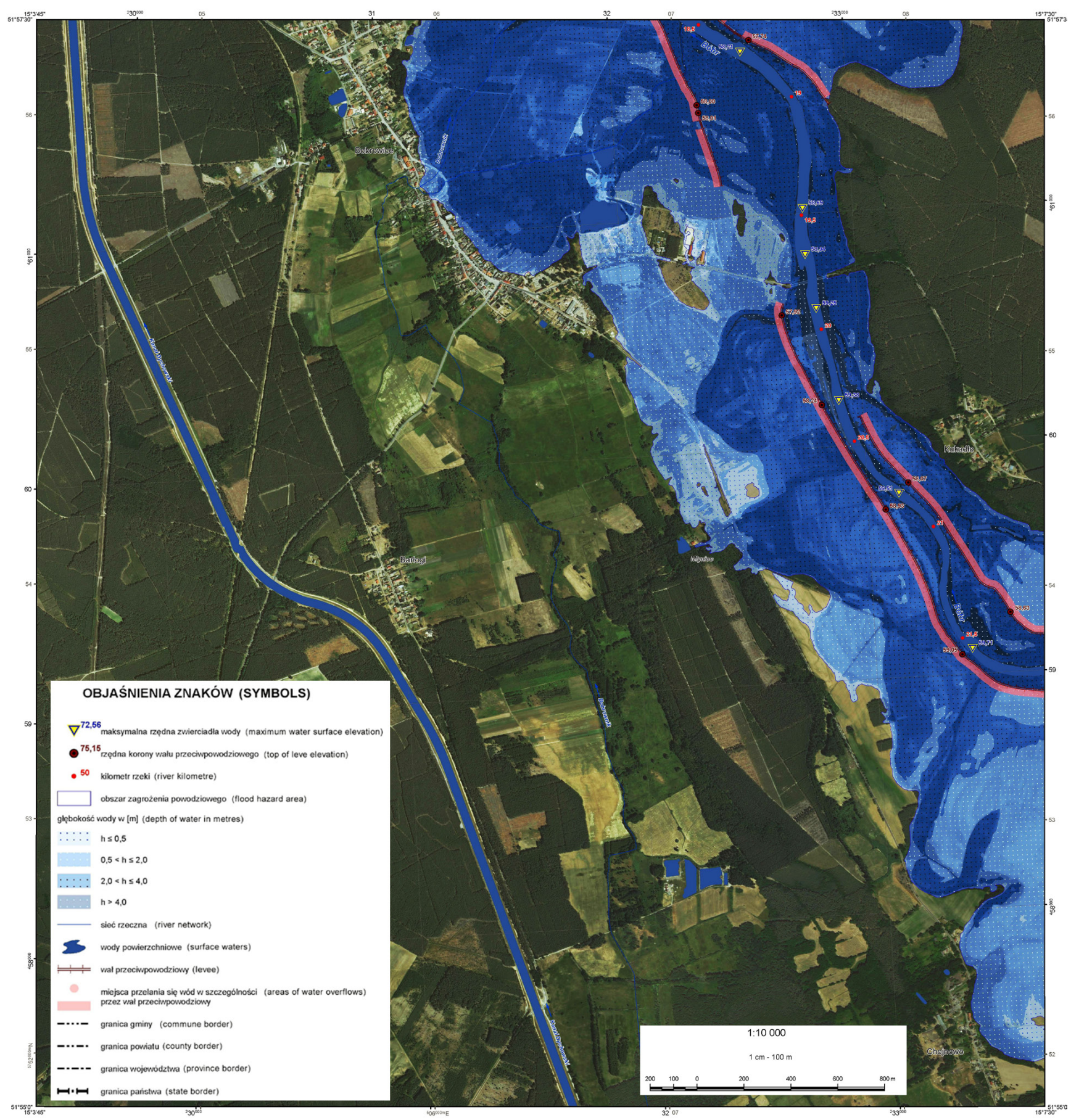

Fig. 1. Example of the flood hazard map with the depth of water indicated for areas in which probability of flood occurrence is low once per 500 years (Q0.2\%): Sheet Bobrowice M-33-7-A-a-4 (access: http://mapy.isok.gov.pl).

purification of water. Taking into account the high rate of development of tourism, limnologists consider the social-economic consequences of the deterioration of the ecological condition of the lake, effects of which, they believe, might be serious (Bogdanowicz et al. 2012).
The authors of the paper focus mainly on the issues concerning identification of these lakes, which participate in the flow of flood waters. Additionally, they consider sensitivity to that hazard assigning the lake a flood hazard class, which depends on the water level elevation over the lake table. 
The analysis of exposure of lakes to flood risk was possible using vector data for flood hazard areas, obtained as a result of mathematical modelling and using data of surface waters included in the Topographic Objects Database (Polish: Baza Danych Obiektów Topograficznych-abbr. BDOT), and also registered on flood hazard maps. The remaining aspects are typical of limnological studies and require detailed data, which are not available in the MZP database.
Based on the vector data of surface waters included in MZP, it was not possible to clearly select the lakes, due to lack of discrimination between the water body types (lakes, ponds). Therefore, the data have been supplemented with information about physiographic objects stored in the database of the National Register of Geographic Names (Polish: Państwowy Rejestr Nazw Geograficznych - abbr. PRNG), from which only lakes were selected (Fig. 2).

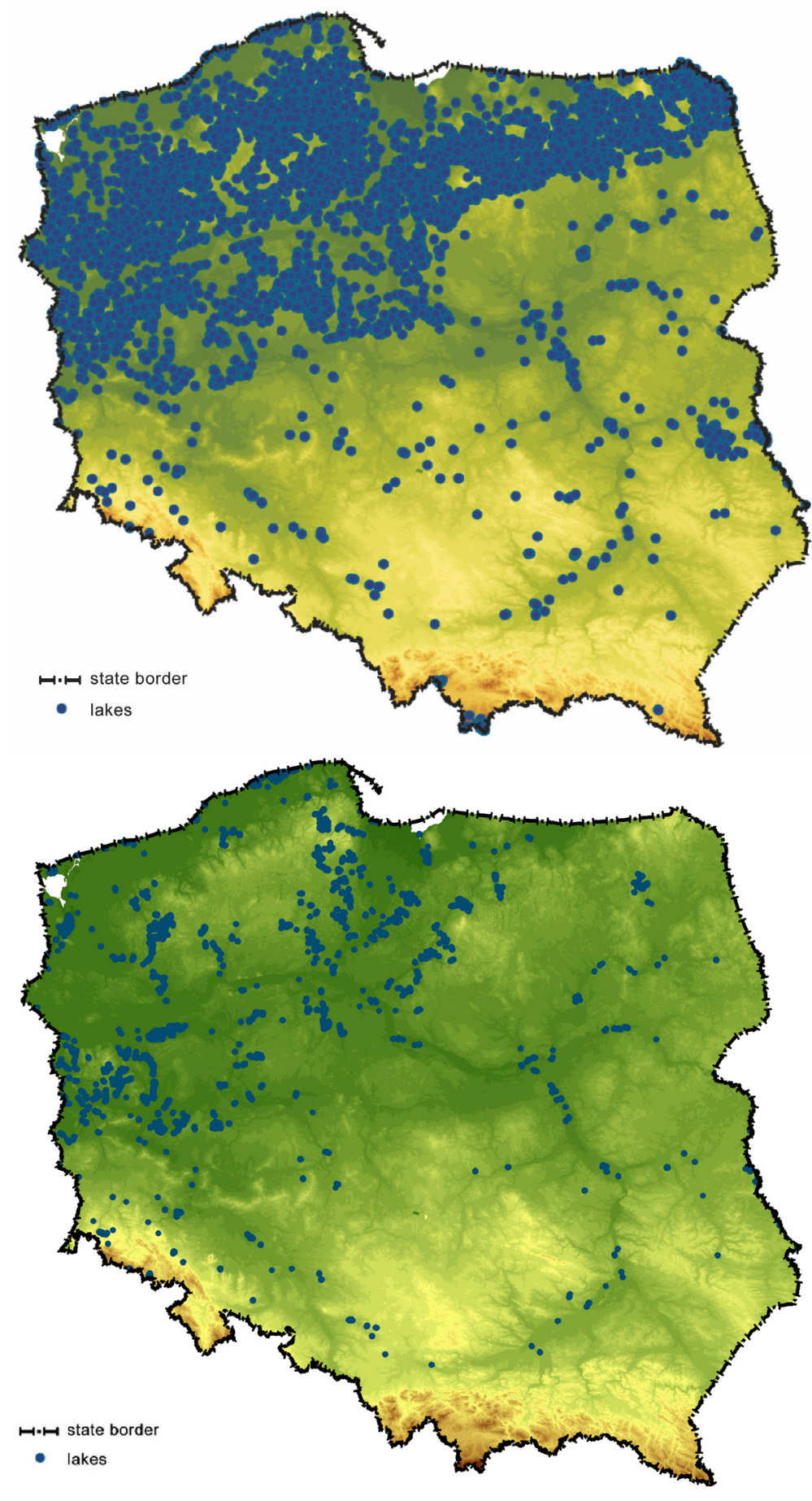

Fig. 2. Map of locations of Polish lakes entered in the National Register of Geographic Names (PRNG)
Fig. 3. Map of locations of Polish lakes subjected to potential losses in their ecosystems caused by flood events. Lakes were selected on the basis of Flood Hazard Maps (MZP) 
Having the point layer of lakes from PRNG and the polygonal layer of still waters from BDOT, based on selection conducted according to location, all objects classified as lakes were selected from BDOT (Fig. 3). After having obtained the proper polygonal layer of lakes it was possible to select those objects which

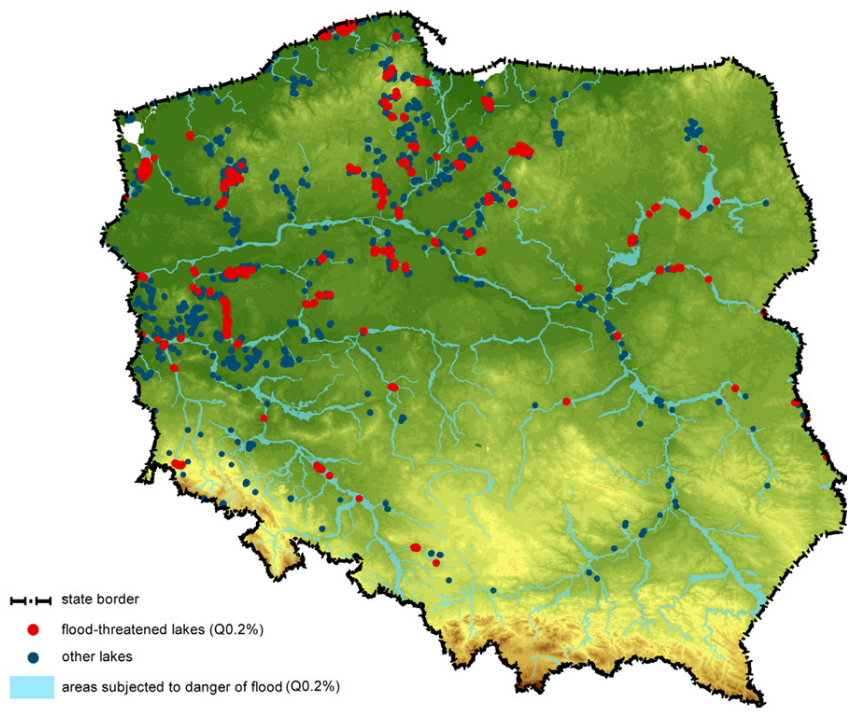

Fig. 4. Distribution map of lakes in Poland exposed to flooding with the probability of occurrence Q0.2\% (once per 500 years)

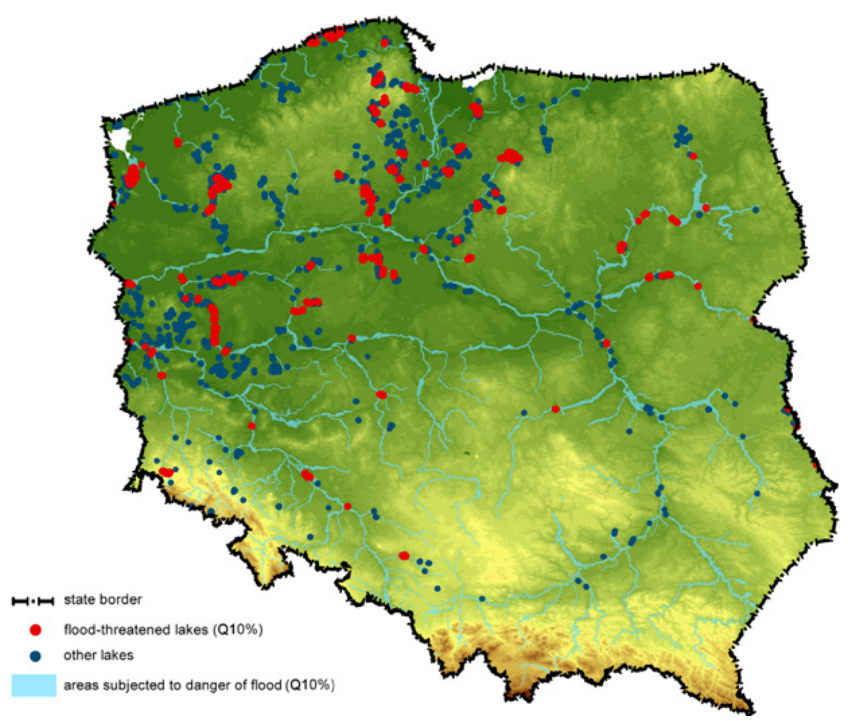

Fig. 6. Distribution map of lakes in Poland exposed to flooding with the probability of occurrence Q10\% (once per 10 years) are located in the flood hazard zones for the three scenarios of probability of flood occurrence: Q0.2\% (Fig. 4), Q1\% (Fig. 5), and Q10\% (Fig. 6).

To illustrate the number of lakes at risk, depending on various flood scenarios, and their spatial distribution, a summarised map has been prepared (Fig. 7).

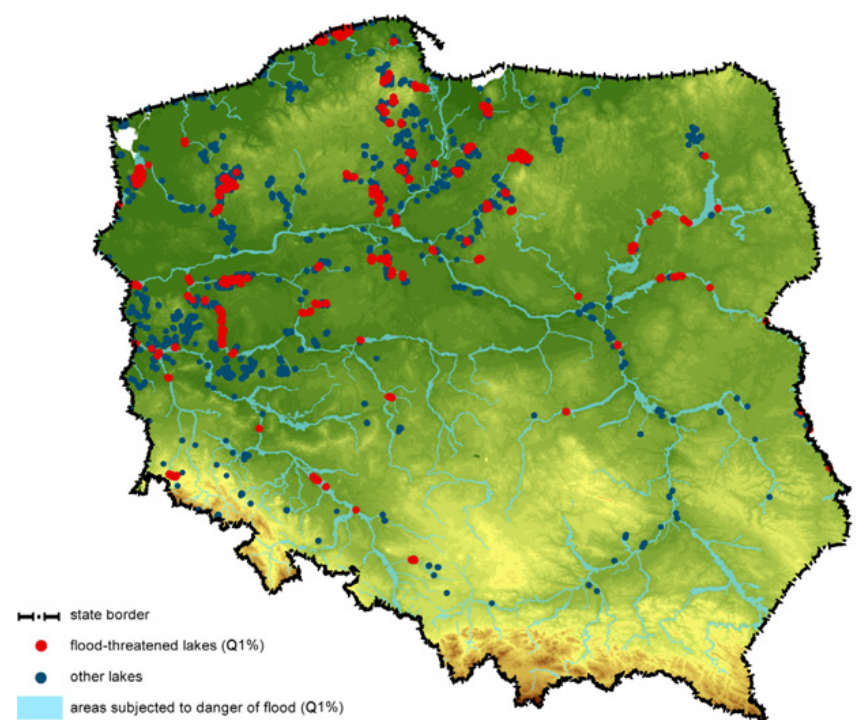

Fig. 5. Distribution map of lakes in Poland exposed to flooding with the probability of occurrence Q1\% (once per 100 years)

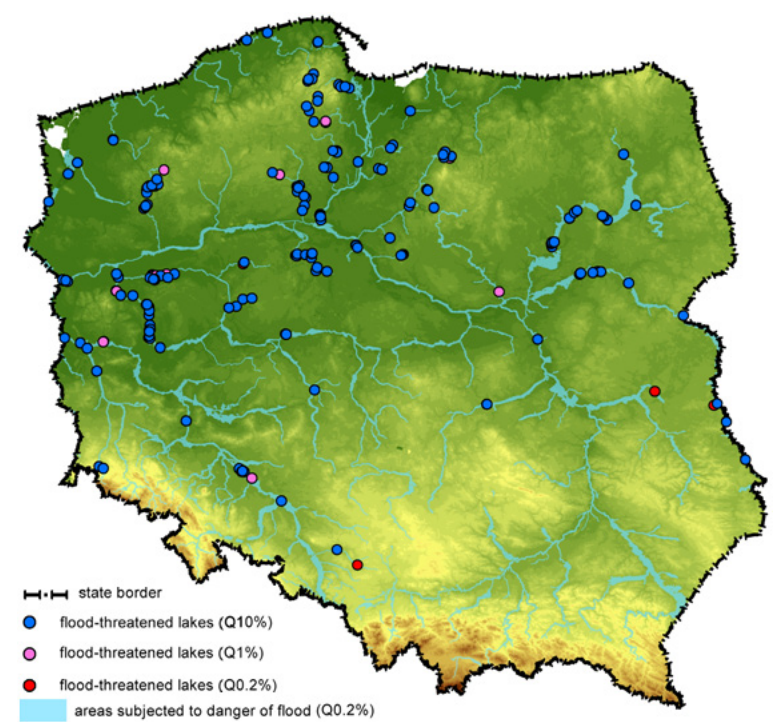

Fig. 7. Summarised map of Polish lakes exposed to flooding with various probabilities of occurrence (Q0.2\%, Q1\%, and Q10\%) 


\section{Results}

As a result of the analysis, 181 lakes have been registered, which are at risk of flood waters. Concerning the probability of flooding there are $181 \mathrm{Q} 0.2 \%$ lakes, 177 Q1\% and 160 Q10\% lakes. The list of all registered objects (lakes) at risk of flooding is presented in tabular form (Table 1). Flood hazard maps, apart from the borderlines of areas under threat, also include information concerning the water depth as well as the water speed and direction, which have a direct impact on the threat for people and on the extent of property losses.
Three levels of threat have been applied to assess the level of threat, depending on the increased elevation of flood waters above the elevation of the water level in the lake (Dumieński, Michalik et al. 2015). For the areas (zones) created this way, relevant indices of a risk have been applied: HIGH, MODERATE, and LOW. Zone I corresponds with the HIGH index, zone II, MODERATE and zone III, LOW. A lake is considered to be under a high threat within the flood hazard area when the increased elevation of flood waters is greater than 2 metres; a moderate threat is within the range of 0.5-2 metres; and a low threat is 0-0.5 metres. The rule used for the division of lakes located in the flood hazard area is presented in Figure 8.

Table 1. Tabular presentation of Polish lakes at risk during flooding.

\begin{tabular}{|c|c|c|c|c|c|c|}
\hline No. & PRNG & LAKE NAME & OPTIONAL NAME & Q0.2\% & Q1\% & Q10\% \\
\hline 1 & 1580 & Bachotek & & + & + & + \\
\hline 2 & 2035 & Bajkał & & + & + & + \\
\hline 3 & 3801 & Berdyczewo & & + & + & + \\
\hline 4 & 4615 & Białe Lake & & + & + & + \\
\hline 5 & 5596 & Białcz & Bielisz/Bielicz/Bielcz & + & + & + \\
\hline 6 & 5645 & Bielkowskie Lake & & + & + & + \\
\hline 7 & 5965 & Biezdruchowo & & + & + & + \\
\hline 8 & 6097 & Binowo & & + & + & + \\
\hline 9 & 6179 & Lake Biskupie & & + & + & + \\
\hline 10 & 6279 & Lake Bledzewskie & Lipawki & + & + & \\
\hline 11 & 6535 & Zbąszyńskie & Lake Zbąszyńskie/Błędno & + & + & \\
\hline 12 & 8285 & Borek & & + & + & + \\
\hline 13 & 9811 & Grajwy & Brajmura/Zalew & + & + & + \\
\hline 14 & 13884 & Bużyska & & + & + & + \\
\hline 15 & 13890 & Bużysko & & + & + & + \\
\hline 16 & 15701 & Lake Chobienickie & & + & + & + \\
\hline 17 & 16779 & Rokitno & & + & + & + \\
\hline 18 & 19906 & Lake Czekanowskie & Głęboczek & + & & \\
\hline 19 & 21012 & Lake Czyste & & + & + & + \\
\hline 20 & 21075 & Czyżno & Czyżon & + & + & \\
\hline 21 & 21649 & Dąbie & & + & + & + \\
\hline 22 & 23475 & Dębno Małe & Dąbie Małe, Małe Dąbie /Dębno Małe & + & + & + \\
\hline 23 & 24131 & Długie Lake & Długie & + & + & + \\
\hline 24 & 24905 & Dobrzeńsko & & + & + & + \\
\hline 25 & 25540 & Lake Pańskie & Dołusze & + & + & + \\
\hline 26 & 26159 & Lake Koronowskie & & + & + & + \\
\hline 27 & 26506 & Druzno & Drużno & + & + & + \\
\hline 28 & 26536 & Drwęckie Lake & Lake Drwęckie & + & + & + \\
\hline 29 & 26720 & Dubie & Dubie Południowe, Adamowo & + & + & + \\
\hline 30 & 27173 & Duża Łacha & & + & + & + \\
\hline 31 & 27192 & Duża Reptówka & & + & + & + \\
\hline 32 & 27305 & Lake Duże & & + & + & + \\
\hline 33 & 27414 & Żurskie Lake & Żur & + & + & + \\
\hline 34 & 28819 & Dzierzgoń & Lake Malborskie & + & + & + \\
\hline 35 & 28967 & Kotowickie Jeziora & Lake Dziewicze & + & + & + \\
\hline 36 & 29779 & Lake Farskie & & + & & \\
\hline 37 & 31708 & Gardno & & + & + & + \\
\hline
\end{tabular}




\begin{tabular}{|c|c|c|c|c|c|c|}
\hline No. & PRNG & LAKE NAME & OPTIONAL NAME & Q0.2\% & Q1\% & Q10\% \\
\hline 38 & 32460 & Lake Gródkowskie & & + & + & + \\
\hline 39 & 33857 & Lake Głuche & & + & + & + \\
\hline 40 & 35115 & Gorzelec & & + & + & + \\
\hline 41 & 37608 & Lake Grabowskie & & + & + & + \\
\hline 42 & 39420 & Lake Grójeckie & & + & + & + \\
\hline 43 & 46755 & Lake & & + & & \\
\hline 44 & 47785 & Lake Juszkowskie & & + & + & + \\
\hline 45 & 53170 & Lake Kierzkowskie & Lake Wójcińskie & + & + & + \\
\hline 46 & 53804 & Kleśno & Lipawki & + & + & \\
\hline 47 & 54633 & Lake Kłosowskie & & + & + & + \\
\hline 48 & 55515 & Kocioł & & + & + & + \\
\hline 49 & 57104 & Konin & & + & + & + \\
\hline 50 & 57643 & Lake Kopanickie & & + & + & + \\
\hline 51 & 57961 & Koperung & Kopaniny & + & + & + \\
\hline 52 & 58635 & Mochel & & + & + & + \\
\hline 53 & 59145 & Kostrzyńskie & Lake Kostrzyńskie & + & + & + \\
\hline 54 & 59447 & Księżno & Lake Kościelne & + & + & \\
\hline 55 & 59725 & Kotło & & + & + & + \\
\hline 56 & 60132 & Lake Kowalskie & Zalew Kowalski & + & + & + \\
\hline 57 & 60922 & Koźlanka & & + & + & + \\
\hline 58 & 61603 & Krąg & & + & + & + \\
\hline 59 & 63338 & Nisko & Lake Krzesińskie & + & + & + \\
\hline 60 & 63502 & Krzemień & Krzemień & + & + & + \\
\hline 61 & 63606 & Krzywa Jama & & + & + & + \\
\hline 62 & 63612 & Krzywa Noga & & + & + & + \\
\hline 63 & 63637 & Lake Krzywanieckie & & + & + & + \\
\hline 64 & 63755 & Lake Krzywe & & + & + & + \\
\hline 65 & 64704 & Kuchnia & & + & + & + \\
\hline 66 & 67387 & Leszcze & & + & + & + \\
\hline 67 & 67715 & Lake Leśniańskie & Lake Sucha & + & + & + \\
\hline 68 & 68132 & Lake Lidzbarskie & & + & + & + \\
\hline 69 & 68567 & Lipiec & & + & & \\
\hline 70 & 68791 & Lipkusz & & + & + & + \\
\hline 71 & 69655 & Kodno & Lake Zaporowe/Lake Lisowskie & + & + & + \\
\hline 72 & 69834 & Liwieniec & & + & + & + \\
\hline 73 & 70148 & Lubie & Lake Lubieszewskie, Lubieszewo, Lake Lube & + & + & + \\
\hline 74 & 70736 & Lake Ludziskie & Ludzisko & + & + & + \\
\hline 75 & 70835 & Lutol & & + & + & + \\
\hline 76 & 70853 & Lake Lutomskie & & + & + & + \\
\hline 77 & 71050 & Łacha & & + & + & + \\
\hline 78 & 71367 & Lake Łapińskie Nowe & & + & + & + \\
\hline 79 & 72361 & Łąki & & + & + & \\
\hline 80 & 72498 & Łebsko & & + & + & + \\
\hline 81 & 72786 & Łęgowo & Lake Łęgowskie & + & + & + \\
\hline 82 & 76240 & Maleszewo & Maliszewo & + & + & \\
\hline 83 & 76272 & Lake Maltańskie & Malta & + & + & + \\
\hline 84 & 76444 & Mała Reptówka & & + & + & + \\
\hline 85 & 76676 & Lake Kierzkowskie Małe & Lake Małe Kierzkowskie & + & + & + \\
\hline 86 & 77192 & Mała Szczekowa & Mały Szeken & + & + & \\
\hline 87 & 78699 & Lake Mączne & & + & + & + \\
\hline 88 & 79844 & Mielno & Dubielno & + & + & + \\
\hline 89 & 79854 & Mielno & Lake Koziejowskie & + & + & + \\
\hline 90 & 81937 & Młyński Staw & & + & + & + \\
\hline 91 & 81971 & Młyńskie & Lake Młyńskie & + & + & + \\
\hline 92 & 81990 & Lake Młyńskie & & + & + & \\
\hline
\end{tabular}




\begin{tabular}{|c|c|c|c|c|c|c|}
\hline No. & PRNG & LAKE NAME & OPTIONAL NAME & Q0.2\% & Q1\% & Q10\% \\
\hline 93 & 82085 & Mniszek & & + & + & + \\
\hline 94 & 83309 & Morliny & Ornowo & + & + & + \\
\hline 95 & 86416 & Nieciecz & & + & + & + \\
\hline 96 & 86540 & Niedziółka & & + & + & \\
\hline 97 & 87189 & Niklerz & & + & + & + \\
\hline 98 & 87744 & Nogat & & + & + & + \\
\hline 99 & 89023 & Nowe Orle & Lake Orle & + & + & + \\
\hline 100 & 89276 & Lake Nowe & & + & + & + \\
\hline 101 & 89795 & Lake Nowowiejskie & & + & + & + \\
\hline 102 & 90927 & Lake Obrzańskie & & + & + & + \\
\hline 103 & 91109 & Zaręba & & + & + & \\
\hline 104 & 91380 & Lake Ogonowskie & & + & + & + \\
\hline 105 & 91731 & Okno & & + & + & + \\
\hline 106 & 95293 & Ostrów & & + & + & + \\
\hline 107 & 99213 & Piaseczno & & + & + & + \\
\hline 108 & 99726 & Lake Piaskowe & & + & + & \\
\hline 109 & 101389 & Lake Piotrkowskie & Lake Piotrkowickie, Lake Piotrkowieckie & + & + & + \\
\hline 110 & 101493 & Piotrowskie Lake & & + & + & + \\
\hline 111 & 102347 & Pławniowice & & + & + & + \\
\hline 112 & 102385 & Płaźno & Płeźno, Pląsno, Dčwierzchno & + & + & + \\
\hline 113 & 102690 & Okrajek & Lake Płytkie & + & + & + \\
\hline 114 & 107011 & Lake Pokrzywnickie & & + & + & + \\
\hline 115 & 107907 & Pomocnia & & + & + & \\
\hline 116 & 110025 & Prądzik & & + & + & + \\
\hline 117 & 110138 & Lake Proboszczowskie & & + & + & + \\
\hline 118 & 110252 & Prostynia & Lake Koziejowskie, Prostyń & + & + & + \\
\hline 119 & 113476 & Pauzeńskie Lake & Lake Pauzeńskie/Puzy & + & + & + \\
\hline 120 & 113857 & Radgoszcz & Lake Radgoskie & + & + & + \\
\hline 121 & 114166 & Lake Raduszeckie & & + & + & + \\
\hline 122 & 115347 & Reskowskie Lake & Reskowo & + & + & + \\
\hline 123 & 118170 & Wielkie Rudno & Grażyna/Rudno/Dubie & + & + & + \\
\hline 124 & 118244 & Lake Ruduskie & Lake Wojnowskie & + & + & + \\
\hline 125 & 119015 & Rybojadło & Rybojadło, Lake Rybojadło & + & + & + \\
\hline 126 & 120209 & Lake Sadłogoskie & Sadłogoszcz & + & + & + \\
\hline 127 & 121649 & Sianowskie Lake & & + & + & + \\
\hline 128 & 122155 & Lake Sieluńskie & & + & + & + \\
\hline 129 & 123504 & Lake Święte & Małe, Mielno, Skępskie & + & + & + \\
\hline 130 & 123505 & Lake Wielkie & Lake Skępskie Wielkie & + & + & + \\
\hline 131 & 124530 & Lake Słodkie & Cisek, Lake Czyżkowskie & + & + & \\
\hline 132 & 124637 & Lake Słone & & + & + & + \\
\hline 133 & 125488 & Smordy & Lake Jakuba & + & + & + \\
\hline 134 & 126521 & Lake Sołeckie & & + & + & + \\
\hline 135 & 129251 & Stare Orle & Lake Orle & + & + & + \\
\hline 136 & 131226 & Stoczek & & + & + & + \\
\hline 137 & 131719 & Lake Straszyńskie & Lake Goszyńskie & + & + & + \\
\hline 138 & 132126 & Strunowo & Stronno & + & + & + \\
\hline 139 & 132460 & Strzelno & & + & + & + \\
\hline 140 & 133905 & Lake Swarzędzkie & & + & + & + \\
\hline 141 & 134440 & Lake Szarlejskie & Szarlej, Gopło, Lake Łojewskie & + & + & + \\
\hline 142 & 135005 & Szczypa & & + & + & + \\
\hline 143 & 136939 & Lake Ślepe & Lake Laskowe & + & + & + \\
\hline 144 & 138210 & Lake Święte & Mień & + & + & + \\
\hline 145 & 140696 & Lake Tryszczyńskie & & + & + & + \\
\hline 146 & 141842 & Turzynek & & + & + & + \\
\hline 147 & 142050 & Lake Tylickie Małe & Lake Środkowe, Małe & + & + & \\
\hline
\end{tabular}




\begin{tabular}{|c|c|c|c|c|c|c|}
\hline No. & PRNG & LAKE NAME & OPTIONAL NAME & Q0.2\% & Q1\% & Q10\% \\
\hline 148 & 142051 & Lake Tylickie & Lake Fabryczne & + & + & + \\
\hline 149 & 146070 & Wielka Łacha & & + & + & + \\
\hline 150 & 146339 & Lake Wielkie & & + & + & + \\
\hline 151 & 146390 & Rybaki & & + & + & + \\
\hline 152 & 146391 & Wielkie Dębno & Dąbie Wielkie & + & + & + \\
\hline 153 & 146406 & Wielkie Lake & & + & + & + \\
\hline 154 & 146407 & Wielkie Lake & Rybno & + & + & + \\
\hline 155 & 146616 & Lake Wielowiejskie & Lake Wielkowiejskie & + & + & + \\
\hline 156 & 147037 & Lake Wierzchnie & Lake Wierzchnie & + & + & + \\
\hline 157 & 147221 & Wierzysko & & + & + & + \\
\hline 158 & 148487 & Wiry & Lake Mostowe & + & + & + \\
\hline 159 & 150535 & Lake Wolickie & Ptur, Pturek, Lake Pturskie & + & + & + \\
\hline 160 & 152024 & Wstążki & & + & + & \\
\hline 161 & 155195 & Zacharz & & + & + & + \\
\hline 162 & 155839 & Zagnanie & & + & + & + \\
\hline 163 & 162014 & Lake Złotnickie & & + & + & + \\
\hline 164 & 162130 & Zły Łęg & & + & + & + \\
\hline 165 & 164030 & Żółwino & Żółwin, Lake Żółwińskie & + & + & + \\
\hline 166 & 164653 & Kamienny Dół & & + & + & + \\
\hline 167 & 201446 & Lake Ośniańskie & & + & + & + \\
\hline 168 & 201447 & Kiszki & & + & + & + \\
\hline 169 & 201754 & Lake Rybackie & & + & + & + \\
\hline 170 & 201833 & Domastryjewo & & + & + & + \\
\hline 171 & 202785 & Czarna Łacha & & + & + & + \\
\hline 172 & 202956 & Sołeczno & & + & + & + \\
\hline 173 & 203552 & Lake Kapeloniaste & & + & + & + \\
\hline 174 & 204058 & Małe Rudno & & + & + & + \\
\hline 175 & 204433 & Gęsie & & + & + & + \\
\hline 176 & 205544 & Ruda Łacha & & + & + & + \\
\hline 177 & 205620 & Lake Jonica & & + & + & + \\
\hline 178 & 205836 & Kotowicko & & + & + & + \\
\hline 179 & 205837 & Lake Panieńskie & & + & + & + \\
\hline 180 & 206319 & Teselak & & + & + & + \\
\hline 181 & 206320 & Wornińskie Lake & & + & + & \\
\hline
\end{tabular}

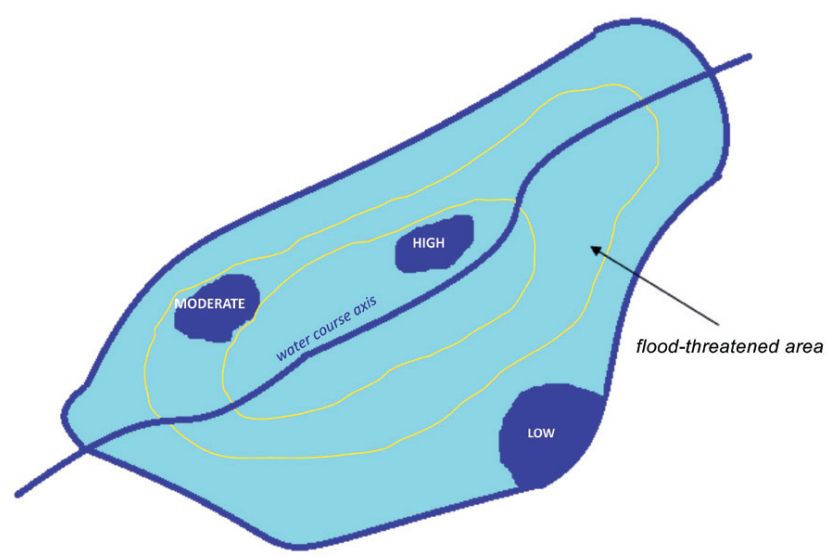

Fig. 8. Delimitation of the areas (zones) for three different levels of flood threat (high, moderate, and low) for lakes
Because the methodology of generation of flood hazard areas used by MZP makes it impossible to directly determine the increased elevation of flood waters over the elevation of the lake water surface, in order to define this value and the threat for lakes associated with this, an additional buffer zone of 100 metres around the lakes' shoreline has been used for the layer of lakes at risk. The lake water surface elevations within a buffer zone defined thus have been estimated, as well as the increased elevations of flood waters over the lake water surface. 
As a result maps showing lakes subjected to potential risk, taking into consideration the threat level of the flooding phenomenon, have been created (Figs 9-11). The threat level is expressed by an increased elevation of flood waters above the elevation of the lake water table for the three scenarios of flooding occurrence probability (Q0.2\%, Q1\%, Q10\%). For the flooding occurrence probability Q $0.2 \%$ scenario, a percentage diagram, showing the share of lakes with different levels of flood threat, has been additionally prepared (Fig. 12).

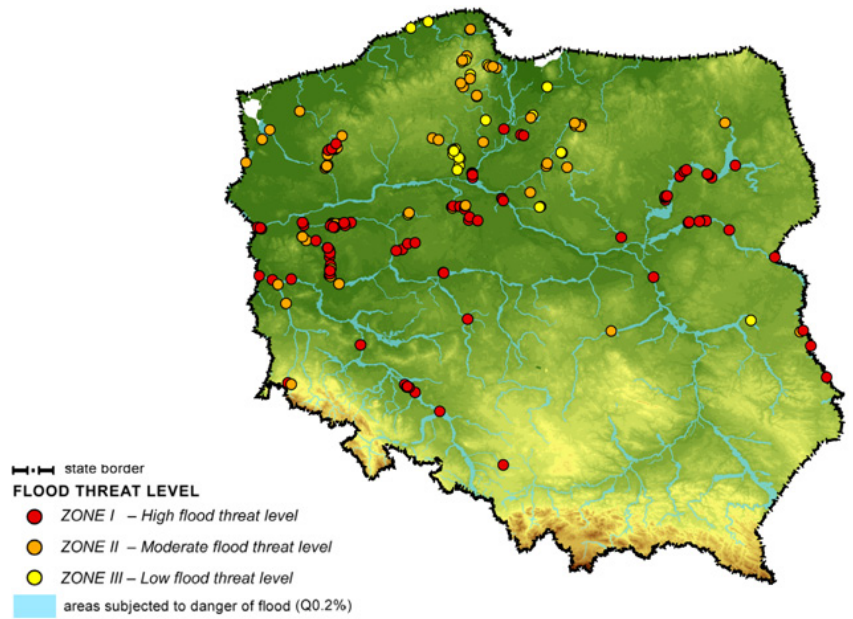

Fig. 9. Distribution map of lakes in Poland exposed to flooding with the probability of occurrence Q0.2\% arranged according to flood threat levels; data from BDOT

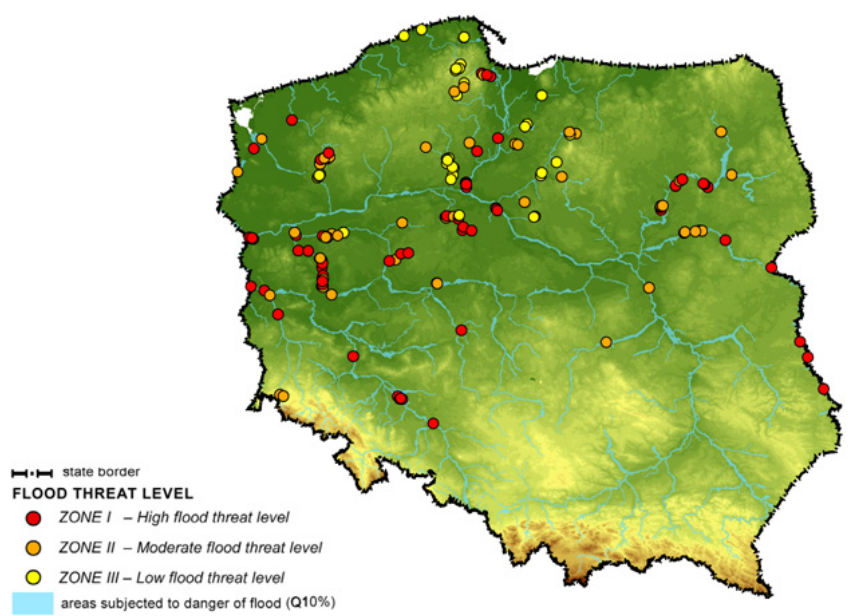

Fig. 11. Distribution map of lakes in Poland exposed to flooding with the probability of occurrence Q10\% arranged according to flood threat levels; data from BDOT

\section{Discussion and Conclusion}

The result of efforts of the team of authors is the determination of the number of lakes, which - based on analyses of flood hazard maps - are located within the zone of the flood risk. The identified lakes are listed in tabular form (Table 1). The maps (Figs 9-11) show the lakes with a division into individual groups, taking into account the level of the flood threat for a lake. This level is expressed by an increased elevation of flood waters above the elevation of the lake water surface. In all scenarios of the probability of flooding

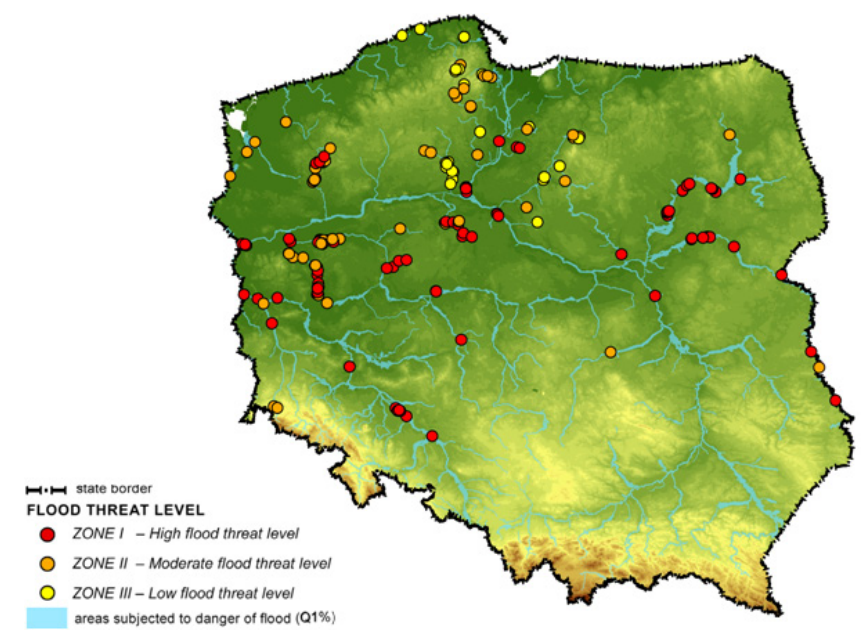

Fig. 10. Distribution map of lakes in Poland exposed to flooding with the probability of occurrence Q1\% arranged according to flood threat levels; data from BDOT

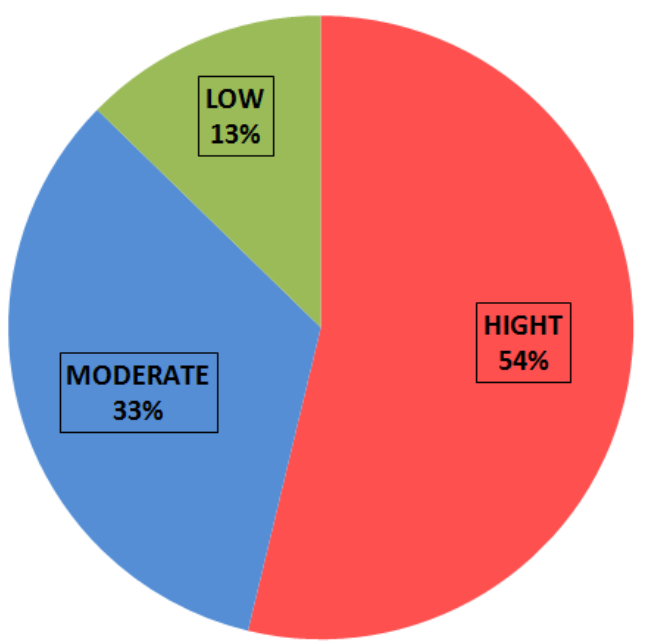

Fig. 12. Differentiation of flood threat level within a group of 181 lakes located within the flood range with the probability of occurrence once per 500 years 
occurrence for which flood hazard maps were elaborated, three groups (levels) of division of the flood threat for lakes have been proposed, i.e. low, moderate and high.

Based on the conducted analysis of lakes' exposure it is evident that 181 lakes are at risk of flooding at probability Q0.2\%, 177 at probability Q1\%, and 160 at probability Q10\%. While analysing the lakes under the threat of Q0.2\% (500-year flood), it should be stressed that over $50 \%$ of these lakes are located within the range of a high threat (over 2 metres). On the scale of the entire country, the greatest number of lakes at risk are found in the Kuyavian-Pomeranian Province.

The area presented in the flood hazard maps, endangered by flood risk, allows us to determine the level of flood risk for this area, through application of the defined loss coefficients for different forms of land development (Dz.U. 2013 poz. 104). In contrast, flood risk in the area under study is characterised by the amount of losses of property caused by flooding with flood waters. However, under the Polish law (Dz.U. 2013 poz. 104), while calculating the amount of losses for the area at risk of flooding, losses originating from the impact of flood waters on surface waters (including lakes), have not been taken into consideration. There are also no loss coefficients assigned for the usage class "waters", or indexation of rates defining potential losses from the moment of publication of the ordinance. This results, on the one hand, in the lack of a full image of flood losses in Poland; on the other hand, it transfers the burden to evaluate the losses in the ecosystem into intermediate costs.

The material presented may contribute to further, more detailed analyses and assessments of vulnerability and resilience of lakes within the area at risk of a flood hazard. Through identification of the lakes (exposure) as well as by assigning flood hazard levels to these objects, the authors initiated the process of determination of their sensitivity, assuming that this constitutes those features and circumstances of the system or its elements which make the system at risk of adverse effects (losses), and their extent depends on the features of the system's elements (UNISDR 2007). Based on the approach adopted in the flood hazard analysis of Polish social-ecological systems, we may receive a comprehensive image of vulnerability, as a resultant exposure (system elements), sensitivity (features of these elements) and adaptation measures (undertaking technical and non-technical actions).

\section{References}

Bogdanowicz E., Marcinkowski M., Nadolna A., Nowicka B. (Polish ver. eds), 2013, Jeziora europejskie pod wpływem stresorów środowiskowych. Tom 1: Charakterystyka jezior i ich współczesnych wrażliwości (European lakes under environmental stressors. Vol. 1: Lakes characterisation and present vulnerabilities), IMGW, Warszawa, pp. 56 (in Polish).

Directive 2007/60/WE of the European Parliament and of the Council of 23 October 2007 on the assessment and management of flood risks, OJ L 288, 6.11.2007: 27-34.

Dumieński G., Michalik M., Pasiecznik-Dominiak A., Tiukało A., 2015, Analiza zagrożenia jezior Polski na niebezpieczeństwo powodzi 10-letniej (Threat analysis of Polish lakes to a 10-year flood), [in:] Wiśniewski R. (ed.), Ochrona i rekultywacja jezior (Protection and restoration of lakes), PZIiTS, Toruń: 31-40 (in Polish, English summary).

Dumieński G., Pasiecznik-Dominiak A., Tiukało A., 2015, Społeczno-ekonomiczna ocena zagrożenienia powodziowego gmin w Polsce (Social-economic assessment of Polish communities to flood threat), [in:] Kotowski A., Piekarska K., Kaźmierczak B. (eds), Interdyscyplinarne zagadnienia $\mathrm{w}$ inżynierii i ochronie środowiska. Tom 6. (Interdisciplinary issues in engineering and environmental protection. Vol. 6), Ofic. Wydaw. Politechniki Wrocławskiej, Wrocław: 100-125 (in Polish, English summary).

Dz.U. 2013 poz. 104, Rozporządzenie Ministra Środowiska, Ministra Transportu, Budownictwa i Gospodarki Wodnej, Ministerstwa Administracji i Cyfryzacji oraz Ministra Spraw Wewnętrznych z dnia 21 grudnia 2012 r. w sprawie opracowania map zagrożenia powodziowego oraz map ryzyka powodziowego (Journal of Laws of the Republic of Poland - Ordinance of the Minister of the Environment, Minister of Transport, Construction and Maritime Economy, Minister of Administration and Digitisation and the Minister of the Interior dated 21st December 2012 concerning development of flood hazard maps and flood risk maps) (in Polish).

Gromek P., 2014, Aspekt społeczny analizy ryzyka ewakuacji ludności w obliczu klęski żywiołowej w Polsce (Social aspect of risk analysis during people's evacuation face-to-face with natural disaster in Poland), Pr. Studia Geogr. 55: 43-53 (in Polish, English summary).

Holling C. S., 1973, Resilience and stability of ecological system, Annual Review of Ecological Systems 4: 1-23 (in English).

[RCB] Rządowe Centrum Bezpieczeństwa (Government Centre for Security), 2012, Zagrożenia okresowe występujące $\mathrm{w}$ Polsce (Periodic threats occurring in Poland), Wydział Analiz RCB, Warszwa: 3-5 (in Polish). 
Strzelecka E., 2014, Budowanie bezpieczeństwa przeciwpowodziowego. Świadomość społeczna i możliwość zmian (Creating flood security. Public awareness and potential for change), Pr. Studia Geogr. 55: 151-161 (in Polish, English summary).

Tiukało A., Dumieński G., 2013, Zbiornik Niedów elementem systemu społeczno-ekologicznego (Niedow reservoir as an element of the social-ecological system), [in:] Wiśniewski R. (ed.), Ochrona i Rekultywacja Jezior (Protection and restoration of lakes), PZIiTS, Toruń: 199-213 (in Polish, English summary).
Tiukało A., Sadowska U., 2015, Metodologia przygotowania planów zarząazania ryzykiem powodziowym (Methodology of preparation of flood risk management plans), Prz. Komunal. 2: 52-58 (in Polish, English summary).

[UNISDR] The United Nations Office for Disaster Risk Reduction, 2007, Terminology. Retrieved from http://www. unisdr.org/we/inform/terminology [Accessed 2015 June 8].

Zwoździak J., 2015 Plany zarządzania ryzykiem powodziowym (Flood risk management plans), Zesz. Komunal. 2(113): 43. (in Polish, English summary). 